\title{
基于地质灾害敏感性的生态安全格局关键区识别与 修复
}

以济南市为例

\author{
薛 强 ${ }^{1}$, 路 路 ${ }^{1,2, *}$, 牛 韧 $^{1}$, 张晓婧 ${ }^{1}$, 杜文强 ${ }^{3}$ \\ 1 生态环境部环境规划院战略规划研究所, 北京 100012 \\ 2 生态环境部环境规划院美丽中国研究中心, 北京 100012 \\ 3 济南市环境研究院, 济南 250000
}

\begin{abstract}
摘要: 区域生态安全格局构建对提升生态系统服务功能提供了重要路径,同时统筹各种生态要素进行生态保护与修复分区也是 新时期做好生态修复的重要举措。以济南市为例,基于现状生态系统类型分布, 聚焦生态本底和地质灾害敏感性的特征,基于 形态学空间格局分析方法和自然保护区结合进行生态源地提取。采用夏季降水、植被覆盖度、坡度 3 个地质灾害敏感性因子修 正基本生态阻力面。并采用最小成本路径方法 (Least-Cost Path method,LCP) 提取生态廊道,构建了市域的生态安全格局。采 用电路理论进行生态关键区域 (生态 “夹点” 和生态障碍点) 的识别, 进一步划分生态修复改善区, 并对此提出针对性的生态保 护修复策略和工程措施。研究表明:1) 市域生态源地的个数为 35 个,面积为 $567.15 \mathrm{~km}^{2}$, 主要类型为林地和草地。空间上主要 分布南部山区。生态廊道 $818.42 \mathrm{~km}$, 平均廊道长度为 $12.99 \mathrm{~km}$, 廊道分布存在较为明显的空间分布差异性,整体呈现出“一屏、 一带、三轴”的生态安全格局。2)识别的生态修复关键区包含生态“夹点” 25 处,历城区生态“夹点”分布最为密集。全市亟需 修复的生态障碍点共 34 处, 面积为 $6.90 \mathrm{~km}^{2}$, 主要分布章丘区。生态改善区共识别 $2994.84 \mathrm{~km}^{2}$, 近期亟需修复的面积为 96.1 $\mathrm{km}^{2}$, 主要分布在长清区、历城区、莱芜区。3) 通过对比生态修复关键区和现状土地利用类型, 因地适宜的制定了生态修复策略 与工程措施布置指引方向。研究结果可为济南市国土空间生态修复规划提供一定的技术支撑, 同时也可为其他地质灾害敏感 性区域的生态修复规划提供指引。
\end{abstract}

关键词: 生态安全格局; 地质灾害敏感性; 生态源地; 电路理论; 生态修复措施

\section{Identification and restoration of key areas of ecological security pattern based on sensitivity to geological disasters: A case study of Jinan City}

\footnotetext{
XUE Qiang ${ }^{1}$, LU Lu $^{1,2, *}$, NIU Ren ${ }^{1}$,ZHANG Xiaojing ${ }^{1}$, DU Wenqiang ${ }^{3}$

1 Institute of Strategic Planning, Chinese Academy of Environmental Planning, Beijing 100012, China

2 The Center for Beautiful China, Chinese Academy of Environmental Planning , Beijing 100012, China

3 Jinan Environmental Research Academy, Jinan 250000, China
}

\begin{abstract}
Construction of a regional ecological security pattern provides an important path to enhance ecosystem service, while the coordination of various ecological elements for ecological protection and restoration zoning is also an important initiative for better ecological restoration in the new epoch. Taking Jinan city as a case study area, we focus on the basal characteristics of regional ecological environment and geohazard sensitivity based on the current spatial ecosystem
\end{abstract}

收稿日期: 2021-04-23; 接收日期: 2021-09-28

* 通讯作者 Corresponding author.E-mail: lulu@ caep.org.cn 
distribution, the ecological source area was extracted based on Morphological Spatial Pattern Analysis and nature reserves. In addition, summer precipitation, vegetation coverage and slope three geohazard sensitivity factors were used to modify the basic ecological resistance surface, and the ecological corridors were identified using Least-Cost Path method (LCP), and as a result, the ecological security pattern of Jinan City was constructed. by the application of circuit theory, critical areas of ecological restoration (ecological pinch point and ecological barrier point) were identified and further demarcated into three different ecological restoration zones, for which targeted ecological protection and restoration strategies and engineering measures were proposed towards those restoration zones. Results indicate that there were 35 ecological sources and covered an area of $567.15 \mathrm{~km}^{2}$, and the main ecosystem types were forestland and grassland. Those sources were mainly distributed in the southern mountainous. The ecological corridors with a total of $1548.36 \mathrm{~km}$ between them, and the average length of the corridor was $12.99 \mathrm{~km}$. All of them constructed a " one screen, one belt and three axes" ecological security pattern. Key areas of ecosystem preservation and restoration were identified based on the circuit theory, including a total of 25 ecological pinch points, 34 ecological barrier points, and $6.90 \mathrm{~km}^{2}$ of it, and the pinch and barrier points mainly distributed in the Licheng and Zhangqiu District, respectively. A total of $2994.84 \mathrm{~km}^{2}$ of ecological improvement areas have been identified, with $96.1 \mathrm{~km}^{2}$ in urgent need of restoration soon, mainly distributed in Changqing, Licheng and Laiwu District. Suggestions of restoration and direction of engineering measures were proposed, with a combination of the spatial ecological characteristics and land use types. The results of the study provide some technical supports for the territorial spatial planning and ecological protection and restoration in Jinan and also provide scientific guidance for other geohazard-sensitive areas.

Key Words: ecological security pattern; geological disaster sensitivity; ecological sources; circuit theory; ecological restoration measures

近年来,在城市化演变过程中,经济社会发展会带来诸多的生态环境问题,如生境质量退化 ${ }^{[1-3]}$ 、景观碎 裂化 ${ }^{[4-5]}$ 、生态流动受阻 ${ }^{[6]}$ 等。而现阶段生态文明理念深人人心 , 城市发展也要求提供更多优质生态产品以 满足人民日益增长的优美生态环境需要。同时对国土空间生态保护与修复的要求也提上了一个新的高度。 如何科学准确的识别生态保护修复的关键区域,并提出统筹“山水林田湖草” 要素的生态修复措施是未来国 土空间生态系统服务功能提升的重要问题 ${ }^{[7]}$ 。

20 世纪 90 年代,世界上诸多学者综合多种学科知识 ${ }^{[8]}$, 已经形成“源地选取、阻力面构建、廊道提取”生 态安全格局的基本方法, 在区域 ${ }^{[8-9]}$ 、流域 ${ }^{[10]}$ 、省 ${ }^{[11]}$ 、城市 ${ }^{[12] 、 \text { 县 }}{ }^{[13]}$ 、局部区域 ${ }^{[14]}$ 也得到了广泛的应用。科学

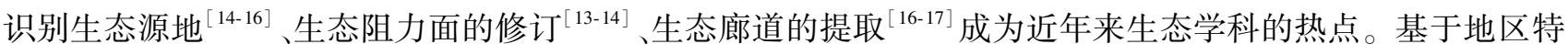
殊生态环境的安全格局的构建是新时期国土空间生态保护和修复重要的一环 ${ }^{[12]}$ 。其中, 生态源地作为生态 格局构建的重要基石, 有守住区域生态安全底线的重要作用。生态源地主要包含自然保护区、森林公园、湿地 公园等具有高生态系统服务功能的用地, 它的选取目前通过评估区域生态系统服务功能重要性和敏感性 ${ }^{[18]}$ 、 生态系统服务价值和景观连通性等方法确定, 其中, 主要涉及模型为生态系统服务和权衡的综合评估模型 (Integrated Valuation of Ecosystem Services and Tradeoffs, InVEST) 模型 ${ }^{[19]}$ 、形态学空间格局分析 (Morphological Spatial Pattern Analysis, MSPA) 方法 ${ }^{[20]}$ 、模型指标法 ${ }^{[21]}$ 。其次,生态阻力面在生态安全格局构建中占有重要 的地位, 而大多数研究中阻力面的构建是将土地利用类型直接赋值的方法, 导致不同地类内部的微观生态流

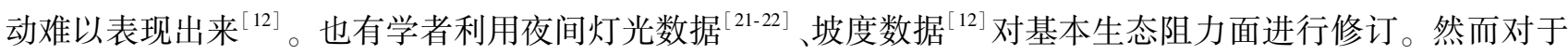
地形种类多、地质情况复杂的山区和平原过渡带,仅依靠上述数据和方法对地质灾害频发的区域进行阻力面 修订,而忽略受季节性降水导致的地质灾害因素对山体的空间局部差异性, 从而导致无法反映出物种在地质 灾害敏感性地带迁移过程中的遇到的阻力。同时地质灾害敏感性对区域生态连通性也会产生一定程度的影 响, 进而导致生物在迁移过程中的阻碍作用加大。因此对特殊地质状况的研究区, 在阻力面构建时需要根据 实际地形进行修订。生态廊道从本质上是基因流动、物种种群动态、种子传播和外来人侵的主要渠道, 对于生 
物多样性的维持具有重要意义。生态廊道的设立可以提高斑块之间的景观连通性,同时在生态廊道中诸如生 态“夹点” 作为生态流动中高流量的关键点, 因其在景观连通性提升中的不可替代性和重要性而成为生态保 护的优先区域 ${ }^{[13]}$ 。生态障碍点将阻碍具有重要生态意义的斑块之间的移动,加强恢复不同障碍点的栖息地 可以最大程度地改善景观连通性 ${ }^{[8]}$ 。在廊道提取中以最小累计阻力模型 (Minimal Cumulative Resistance,

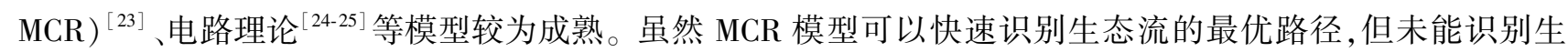
态流动中的廊道范围和生态 “节点” 和障碍点 ${ }^{[26]}$ 。而电路模型中可以高效、科学的识别生态网络内部的生态 流动过程。在电路理论模型中将景观类型作为导电表面, 低电阻能促进生物流动的景观类型, 而阻碍了生物 流动的景观类型则被赋予高电阻。通过电路理论对生态 “夹点” 和障碍点进行系统识别并提出生态修复措 施, 在对地质情况复杂的景观内部生物流动预测、提升景观连通性以及区域生态安全格局的完整性和稳定性 具有重要的作用 ${ }^{[12-13]}$ 。

目前国土空间生态保护与修复研究主要针对微观尺度受损的生态空间修复, 主要有矿山生态修复 ${ }^{[14]}$ 、国

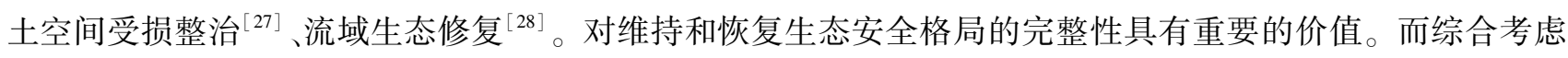
各类生态要素后构建的生态安全格局对系统提升生态系统服务功能也有一定的作用 ${ }^{[9]}$ 。通过科学的技术对 地质灾害敏感性的生态修复的关键区域进行系统识别, 尤其在明确提出基于本地化的系统的生态修复工程指 引等方面的研究仍然有待加强。

本文以地质灾害较为敏感的济南市为例, 通过形态学空间格局分析方法、结合自然保护地识别生态源地, 基于地质灾害敏感性构建生态阻力面, 利用电路理论模型提取生态廊道, 并结合土地利用现状识别生态保护 修复的关键区域 (生态 “夹点” 和生态障碍点), 最后进行生态修复保护分区并提出相应的生态修复策略和系 统性的生态修复工程, 以期为济南市生态安全格局和生态修复提供参考。

\section{1 研究方法与数据来源}

\section{1 研究区概况}

济南市介于 $116^{\circ} 13^{\prime}-117^{\circ} 58^{\prime} \mathrm{E}, 35^{\circ} 57^{\prime}-37^{\circ} 32^{\prime} \mathrm{N}$ 之间, 位于鲁中山区北侧, 总面积为 $10244 \mathrm{~km}^{2}$ 。南依 泰山, 北跨黄河。市域地形为南高北低, 具体为北部临黄带, 中部山前平原带, 南部丘陵山区带。多年平均气 温为 $13.8^{\circ} \mathrm{C}$, 年平均降水量 $685 \mathrm{~mm}$, 雨季为 6-9 月。境内流域主要有黄河、小清河、大汶河、南四湖等。泉水 丰富,包括跑突泉、黑虎泉等十大泉群, 具有 “山、泉、湖、河、城” 的独特风貌。主要土地利用类型为农田、林 地、建设用地 (图 1)。然而近年来, 由于气候变化、人类活动的影响加之特殊的地质环境, 区域内发生的崩塌、 滑坡、泥石流、以及地裂缝等地质灾害频发, 根据《全国地质灾害通报》(2019 年) 济南市共发生地质灾情 27 起,转移受威胁群众 431 人 $^{[29]}$, 给人民的生命和财产安全构成了威胁。

\section{2 数据来源与处理方法}

全球地表覆盖数据 GlobeLand 30 (2020 年) 空间分辨率为 $30 \mathrm{~m}$, 样本数超 23 万个, 总体精度为 $85.72 \%$ (http://www.globallandcover.com/)。数字高程模型 (Digital Elevation Model, DEM) 来源于地理空间数据云平 台 (http://www.gscloud.cn/)。归一化植被指数 (Normalized Difference Vegetation Index, NDVI) 数据来源于中 国科学院资源环境数据中心 (http://www.resdc.cn/Default.aspx), 分辨率为 $1 \mathrm{~km}$ 。月降水数据来源于国家地

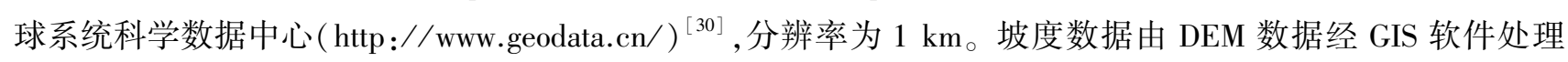
得到。高速公路、铁路来源获取自水经注地图。LandScan2019 全球人口动态统计分析数据库由美国能源部 橡树岭国家实验室 (ORNL) 开发, East View Cartographic 提供 (https://landscan.ornl.gov/landscan-datasets)。 所有数据经过投影至 CGCS2000 坐标系, 裁剪后得到研究区数据, 最后统一转换为 $100 \mathrm{~m} \times 100 \mathrm{~m}$ 的栅格数据。

\subsection{1 生态源地的识别}

生态源地是区域生态网络构建的重要基础, 对区域的生态格局、生物多样性以及生态安全有着重要的影 响 ${ }^{[19]}$ 。生态源地面积的大小与物种多样性的丰富程度呈现出正相关的关系 ${ }^{[31]}$ 。本文将林地、草地、灌木、湿 


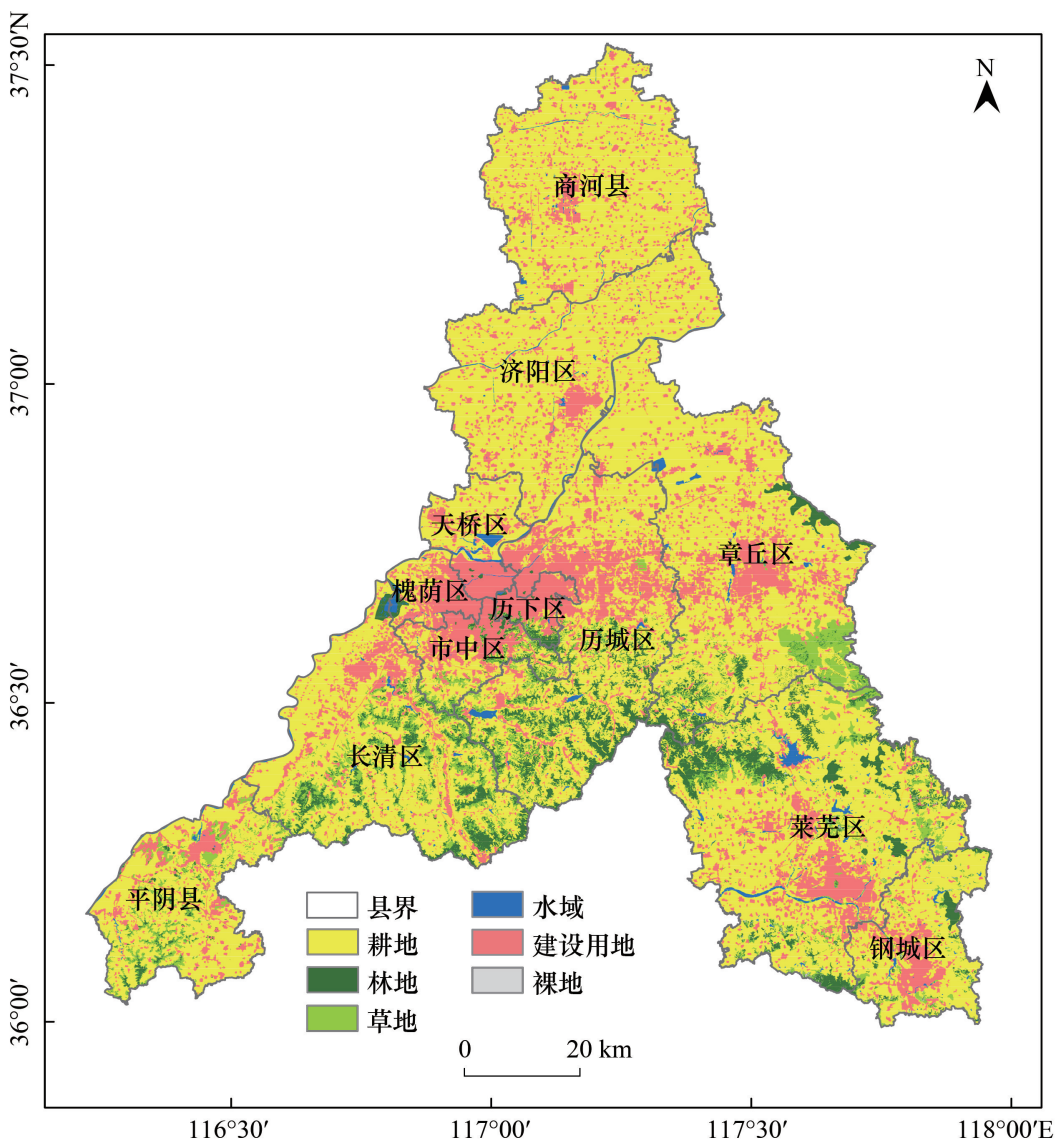

图 1 济南市土地覆盖图

Fig.1 Land cover map of Jinan City

地、水体作为 MSPA 模型的前景数据, 其余数据作为背 景数据, 最后得到七种景观类型 (图 2), 将面积大于 2 $\mathrm{km}^{2}$ 的核心区作为初选生态源地。考虑到景观结构的 空间连接程度会影响生物迁徙过程 ${ }^{[32]}$, 因此通过计算 斑块中景观格局指数中的可能连通性指数 $(d P C)$ 识别 各景观斑块中的连通性强度 ${ }^{[33-34]}$ 。确定好初选生态源 地后, 在 Conefor 2.6 设置 $1500 \mathrm{~m}$ 为斑块连通距离阈 值 ${ }^{[35-37]}$, 当各斑块间之间的成本值在确定阈值内部时, 认为两个斑块之间是连通的, 根据学者研究, 斑块连通 性与距离阈值成正相关关系 ${ }^{[38]}$, 连通概率设置为 0.5 , 将生态斑块 $d P C$ 值大于 0.1 的生态源地划分为最终生 态源地 ${ }^{[36]}$ 。最后将生态源地与济南市自然保护区名录 相互对照,发现自然保护区名录中的自然保护区和森林 公园、湿地公园均包含在内。

\subsection{2 生态阻力面的修订}

生物在不同生态源地的迁徙过程中,需要克服不同 的土地利用类型进行生物交流。本文采用土地利用、高

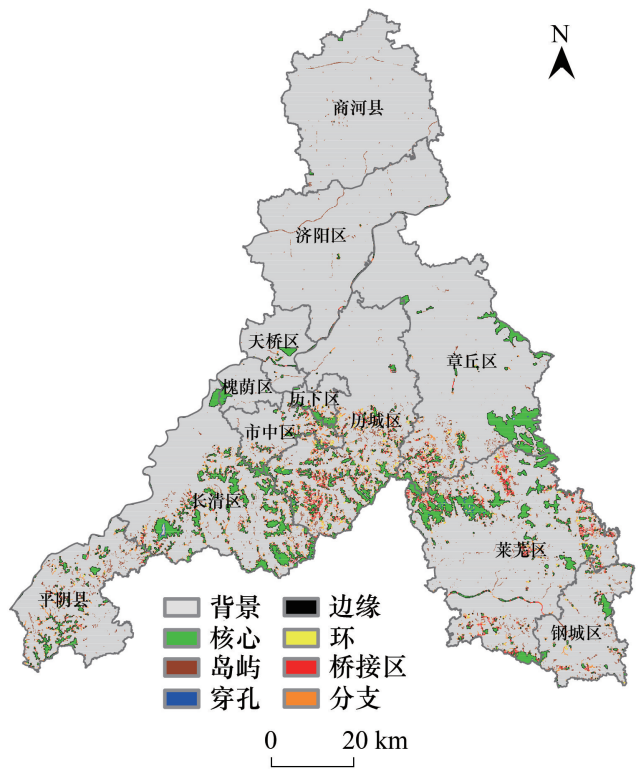

图 2 形态学空间格局分析结果

Fig.2 The Result of Morphological Spatial Pattern Analysis 
程、以及人类可达性(距高速公路、国道/省道、铁路距离)共计三大类因子构建基本生态阻力面。基本阻力面 共包含 5 个阻力因子, 然后使用地理空间分析中最大值的模糊叠加方法进行基本阻力栅格因子的叠加。在阻 力值赋值时, 通过参考已有学者 ${ }^{[39-40]}$ 的研究和咨询相关专家确定, 不同类别的因子权重利用层次分析法得到 (表 1)。

表 1 基本生态阻力面赋值及权重

Table 1 Assignment and weight of basic ecological resistance surface

\begin{tabular}{|c|c|c|c|}
\hline $\begin{array}{l}\text { 阻力因子 } \\
\text { Resistance factors }\end{array}$ & $\begin{array}{l}\text { 分级 } \\
\text { Class }\end{array}$ & $\begin{array}{c}\text { 阻力值 } \\
\text { The value of resistance factors }\end{array}$ & $\begin{array}{l}\text { 权重 } \\
\text { Weight }\end{array}$ \\
\hline 土地利用 & 林地 & 1 & 0.61 \\
\hline \multirow[t]{6}{*}{ Land use types } & 草地 & 10 & \\
\hline & 湿地 & 30 & \\
\hline & 水体 & 50 & \\
\hline & 耕地 & 100 & \\
\hline & 裸地 & 250 & \\
\hline & 人造地表 & 500 & \\
\hline 高程 & $<200$ & 2 & 0.14 \\
\hline \multirow[t]{4}{*}{ Elevation } & $200-500$ & 4 & \\
\hline & $500-1000$ & 6 & \\
\hline & $1000-1200$ & 8 & \\
\hline & $>1200$ & 10 & \\
\hline 人类可达性-距高速公路 & $0-90 \mathrm{~m}$ & 8 & 0.25 \\
\hline \multirow[t]{2}{*}{ Human accessibility-distance to highway } & $90-500 \mathrm{~m}$ & 6 & \\
\hline & $500-1000 \mathrm{~m}$ & 4 & \\
\hline 人类可达性-距国道/省道 & $0-90 \mathrm{~m}$ & 6 & \\
\hline Human accessibility-distance to National/ & $90-500 \mathrm{~m}$ & 4 & \\
\hline Provincial highway & $500-1000 \mathrm{~m}$ & 2 & \\
\hline 人类可达性-据铁路距离 & $0-90 \mathrm{~m}$ & 8 & \\
\hline \multirow[t]{2}{*}{ Human accessibility-distance to railway } & $90-500 \mathrm{~m}$ & 6 & \\
\hline & $500-1000 \mathrm{~m}$ & 4 & \\
\hline
\end{tabular}

研究区地处山区和平原的交错带,地质构造复杂多样。地质灾害可能会通过改变地形地貌,进一步会影 响本地固有生态廊道, 从而一定程度上会影响物种之间的交流和生态廊道的连通性 ${ }^{[41-42]}$ 。崩塌、滑坡、泥石 流等地质灾害类型通过改变生态系统类型进一步会对区域内的物种迁移和生物多样性有直接或者间接的影 响 ${ }^{[43]}$ 。这些岩土体的位移灾害主要与夏季降水、植被覆盖度、坡度有关 ${ }^{[44-46]}$ 。因此,本研究选取以上 3 个因 子, 将上述的因子归一化后等权重叠加得到济南市地质灾害综合敏感性评价,并基于该因子对上文构建的基 本阻力面进行综合因素修正。修正的公式如下,地质灾害修订因子和修正后的生态阻力面见图 3。

$$
R_{i}=\frac{N L_{i}}{N L_{m}} \times R_{0}
$$

式中, $R_{i}$ 为基于地质灾害修正的栅格 $i$ 的生态阻力系数; $N L_{i}$ 为第 $i$ 个栅格的地质灾害综合敏感度; $N L_{m}$ 为第 $i$ 个栅格对应的基本阻力面类型 $\mathrm{m}$ 的平均地质灾害综合敏感程度; $R_{0}$ 为第 $i$ 个栅格对应第 $i$ 中基本阻力面类型 的阻力系数。

\subsection{3 基于最小成本路径方法识别生态廊道}

本研究基于最小成本路径的方法 (Least-Cost Path method, LCP) 识别生物在各种生态源地中迁徙过程中 面对不同景观阻力面时所需要克服的累计阻力值。依次对每个源地与相邻的源地进行分析, 再对所得到的廊 道进行合并和去几,将模拟得到的最小费用路径当作为最终生态廊道。 

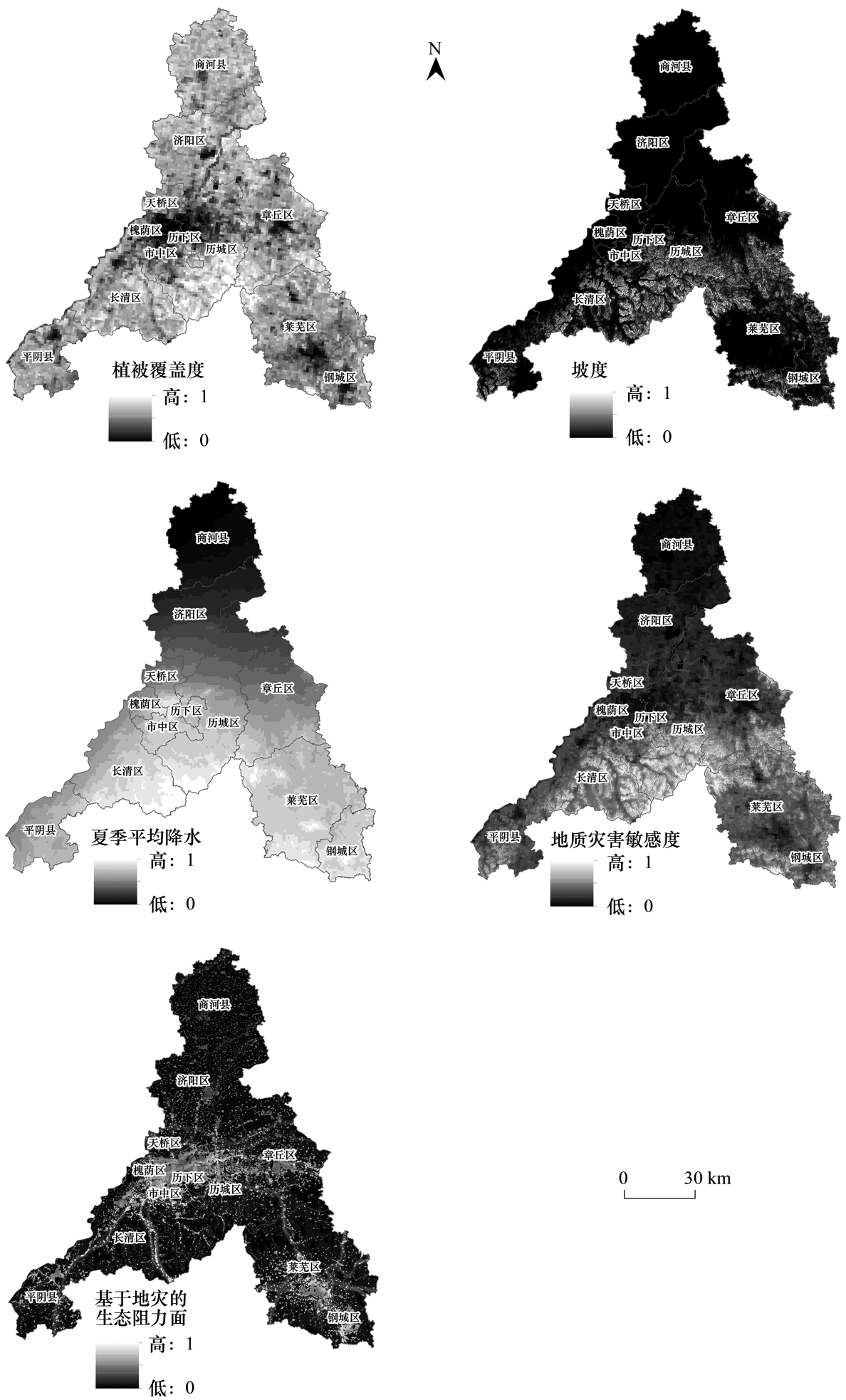

图 3 地质灾害敏感性评估以及生态阻力面的分布

Fig.3 Assessment of geological hazard sensitivity and the distribution of ecological resistance surface

\subsection{4 基于电路理论的生态夹点和障碍点的识别}

电路理论是将物理学中的电子随机游走的特性借鉴到生物在生态源地迁徙过程中, 该理论可以确定预留 哪些生境来加强生态网络的连通性, 从而加强整合了生物的所有可能途径 ${ }^{[25]}$ 。本研究使用 Linkage Mapper 
Toolkit 工具中的 Pinchpoint Mapper 模块来识别生态廊道中的存在的生态“夹点”, 也就是电流密度大的区域, 该区域若有小面积损失也会对生态廊道连通性造成一定的损害。本文选择“All to one”模式进行计算。考虑 到区域整体景观的连通性和生态夹点的位置并不受到廊道的宽度变化而受到影响。故本研究设置廊道加权 成本距离为 $8000 \mathrm{~m}$ 。

生态障碍点通过 Barrier Mapper 模块进行识别,采用改进得分相对于最小成本路径百分比的方法进行障 碍点的识别。这种模式选择既可以选择影响区域内生态流运行的完全障碍点和也可识别部分障碍区域但不 完全障碍的区域 ${ }^{[47-49]}$ 。通过对完全障碍点和不完全障碍点的识别可以增强生态源地之间的连通性。模型计 算时设置为“Maximum”计算模式,迭代半径为设置为 $200 \mathrm{~m}$ 。

一般而言, 对关键区域进行分区研究是开展生态修复的重要一步,生态修复区是区域内具有较强改善意 义的生态空间,改善此类区对提升整体生态安全和增强生物多样性具有重要的意义 ${ }^{[50]}$ 。本文利用 Barrier Mapper 插件将已识别的生态障碍区, 根据障碍区的分布范围和改善系数,将改善系数按照自然断点法由高到 低划分为生态极重要改善区、重要改善区、一般改善区 3 类生态修复改善区。并对划分后的不同类型生态改 善区提出针对性的生态修复方向的措施。

\section{2 结果分析}

\section{1 生态源地的确定}

本文在生态源地最小面积阈值选取的过程中, 研究 了生态斑块数目、生态源地占 MSPA 模型确定的生态核 心区面积的比例与源地最小面积的关系 (图 4)。生态 源地斑块数随着最小面积阈值的增大呈现出减少的趋 势,生态斑块数最多为 1731 个, 此时对应的生态核心区 全域面积为 $559.25 \mathrm{~km}^{2}$ 。最小面积阈值在 $0-0.5 \mathrm{~km}^{2}$ 时, 生态源斑块呈现剧烈下降的趋势, 下降到 138 个。 当最小面积阈值在 $0.5-2 \mathrm{~km}^{2}$ 时,生态源斑块缓慢下 降, 从 138 个下降到 45 个。当最小面积阈值大于 $2 \mathrm{~km}^{2}$ 时,生态斑块数目下降基本稳定, 此时生态斑块数与最 小面积阈值的一阶导数接近为 0 。可以看出, 最小面积 的阈值选取会对生态源地面积有一定的影响,但小于 2 $\mathrm{km}^{2}$ 的 1686 个生态斑块 (占比为 $97.40 \%$ ) 占核心区的 面积比例不到 $30 \%$ 。

本研究通过 MSPA 模型共识别生态景观要素面积 共 $1359.47 \mathrm{~km}^{2}$, 其中核心区 $567.15 \mathrm{~km}^{2}$, 面积占比为 $41.7 \%$, 景观类型多为林地和草地, 其次为水域。南部 山区部分区域景观集聚程度明显,面积较大且稳定性较 强。西南部、中部、东南部地区生态斑块分布较为分散 且破碎化较为严重。说明研究区南部的核心斑块连通 性较差, 生态流动相对较为困难。共识别出 35 个生态 源地, 面积为 $567.15 \mathrm{~km}^{2}$, 占市域面积的 $5.54 \%$ 。最大 的生态源地面积为 $74.18 \mathrm{~km}^{2}$, 最小的生态源地面积为

\section{$2.15 \mathrm{~km}^{2}$ 。}

\section{2 生态廊道的提取结果}

生态廊道是生态安全格局重要组成部分,一般是一

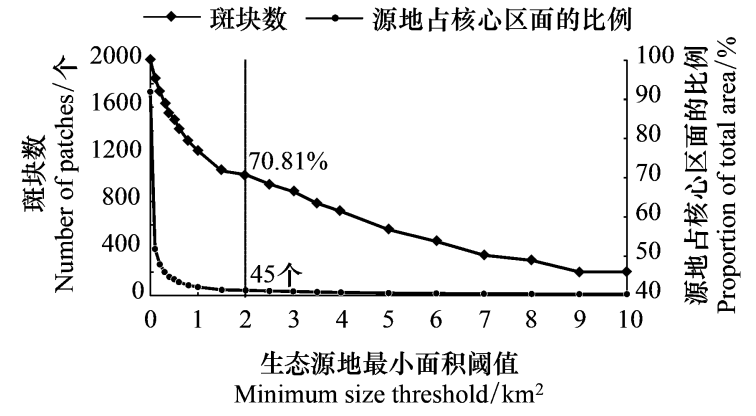

图 4 生态源地最小面积阈值的选取

Fig.4 Selection of the minimum size threshold of ecological sources

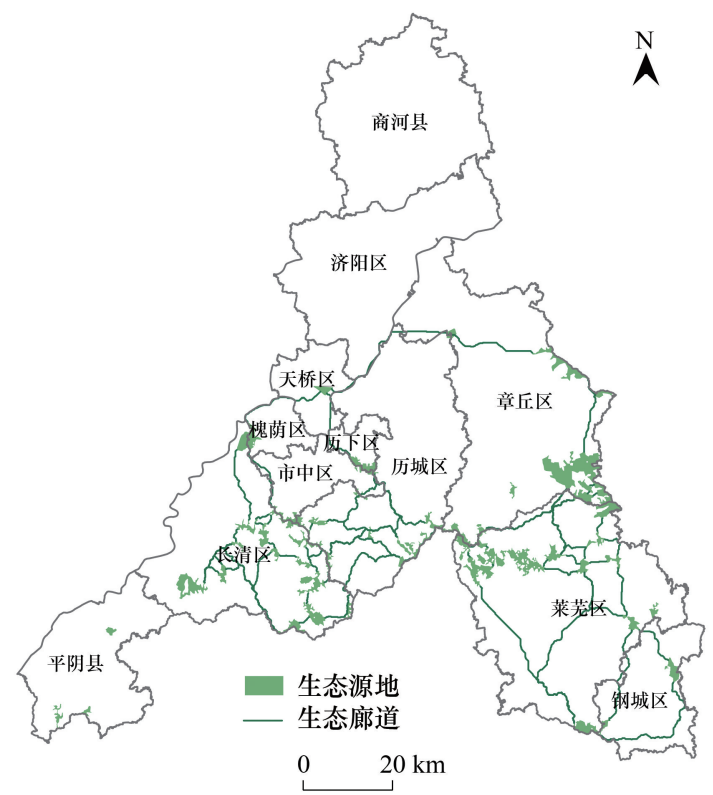

图 5 生态源地和生态廊道分布

Fig.5 Distribution of ecological sources and ecological corridors 
定宽度的条状区域。本文共得到 63 条生态廊道(图 5) 长度介于 $0.28-58.47 \mathrm{~km}$, 总长度为 $818.42 \mathrm{~km}$, 平均廊 道长度为 $12.99 \mathrm{~km}$ 。全市廊道空间分布存在明显差异, 中南部地区廊道丰富、阻力低; 北部廊道分布较为稀 疏, 阻力处于高值。受城市建成区扩张以及南部山区部分生态用地被占用, 部分源地之间虽然有潜在的相互 连接的趋势, 但并未模拟出完整的生态廊道。生态廊道是各个生态源地加强孤立斑块之间的联系, 市域总体 呈现出“一屏、一带、三轴、多点” 的生态安全格局。“一屏”指南部山区生态安全屏障, 从长清区至莱芜区北 部,整体沿地势相对较高的南部山区边界延伸,主要承担区域水源涵养和维持生物多样性的重要的生态系统 服务功能, 是维护好济南生态安全的重要底线。“一带” 是指沿黄生态保护带, 从西南到东北区域沿黄跨过市 区, 主要连接了济西国家湿地公园、鹊山水库等重要生态源地。“三轴”主要是自西向东依次是:玉符河、小清 河、大清河生态保育轴。“多点” 是由济西国家湿地公园、鹊山水库等生态保护区组成的生态源点。总体而 言, 济南市生态廊道主要分布在植被覆盖度高、降水量较高的山区, 大部分避开了地质灾害敏感度较高的区 域,为生态源地彼此间增加物种信息交流、能量流动、物质循环搭建了桥梁。

2.3 生态夹点与障碍点的识别与修复策略

本研究初步识别的生态 “夹点” 如图中红色区域 (图 6)。为保持生态系统的完整性、连续性和便于管理 性, 本研究将过于破碎的细小的生态 “夹点”进行去除, 最终识别的生态 “夹点” 共 25 处, 总面积为 $16.16 \mathrm{~km}^{2}$, 主要分布在山区廊道的交叉点。其中, 历城区生态 “夹点” 数量最多共计 14 个, 面积为 $8.58 \mathrm{~km}^{2}$, 占比最大; 长 清区 3 个, 面积为 $2.60 \mathrm{~km}^{2}$; 章丘区 3 个, 面积为 $1.94 \mathrm{~km}^{2}$, 分布面积占比最小; 莱芜区 2 个, 面积为 $3.04 \mathrm{~km}^{2}$ 。

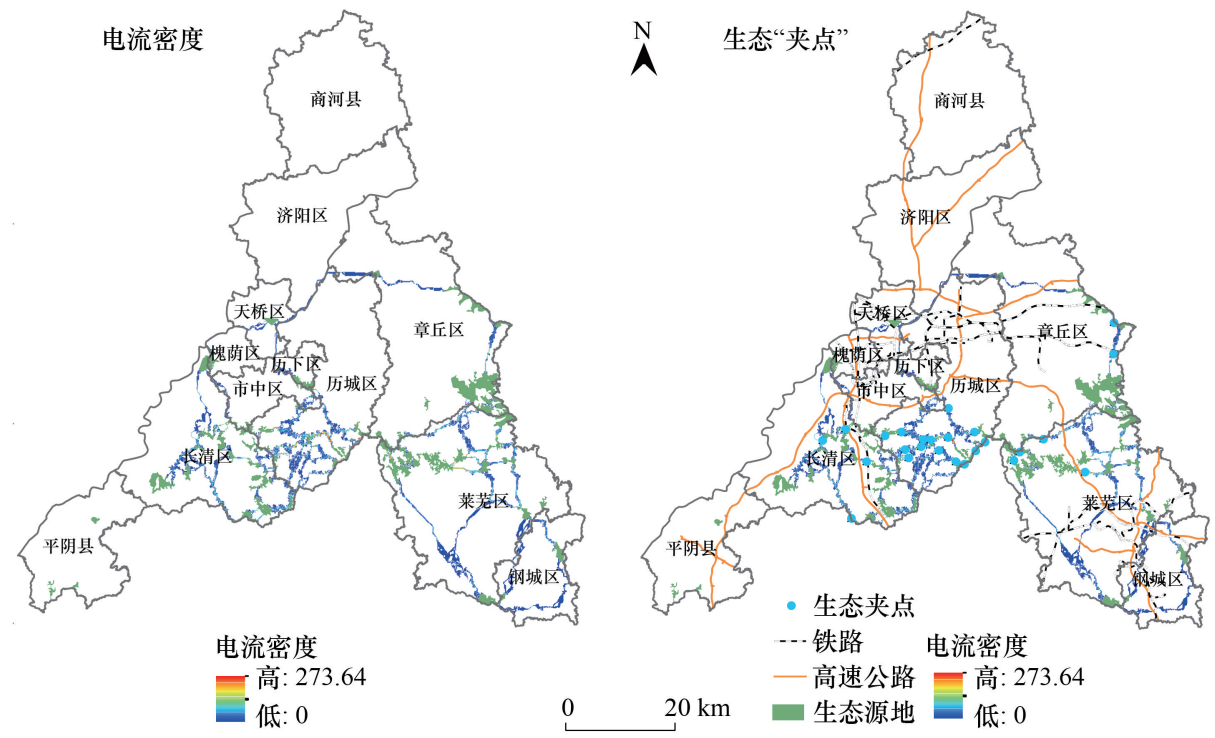

图 6 生态夹点的识别

Fig.6 Identification of ecological pinch point

生态障碍点的识别结果如图 7 所示, 由蓝到红的代表着改善区域的重要性,红色代表亟需改善的区域就 是生态障碍点。共识别生态障碍点 34 处, 面积为 $6.90 \mathrm{~km}^{2}$ 。其中, 长清区的障碍点最为 8 个, 面积为 1.26 $\mathrm{km}^{2}$, 占比为 $18.26 \%$; 莱芜区 9 个, 面积为 $1.46 \mathrm{~km}^{2}$; 历城区 10 个, 面积 $0.74 \mathrm{~km}^{2}$; 章丘区 7 个, 面积为 3.44 $\mathrm{km}^{2}$, 占比最大为 $49.86 \%$ 。其中面积低于 $0.2 \mathrm{~km}^{2}$ 的障碍点个数为 23 个, 个数占比为 $67.6 \%$, 此类障碍点修复 难度较小, 修复完成后对区域整体生态连通性有较大提升幅度。障碍点大部分位于生态廊道的范围生境内。 现状用地类型为园地、农田、建设用地、居民点等,此类用地的共同点就是下垫面硬化程度较高, 对生境质量的 连通性有一定的割裂行为。

针对识别出的关键区域的生态“夹点” 和障碍点, 提出相应的生态保护修复措施 (表 2)。在生态“夹点” 中, 待保护修复的林地、农田、园地分别占总节点面积的 $58.20 \% 、 15.35 \% 、 12.90 \%$ 。在障碍点中, 待保护修复 


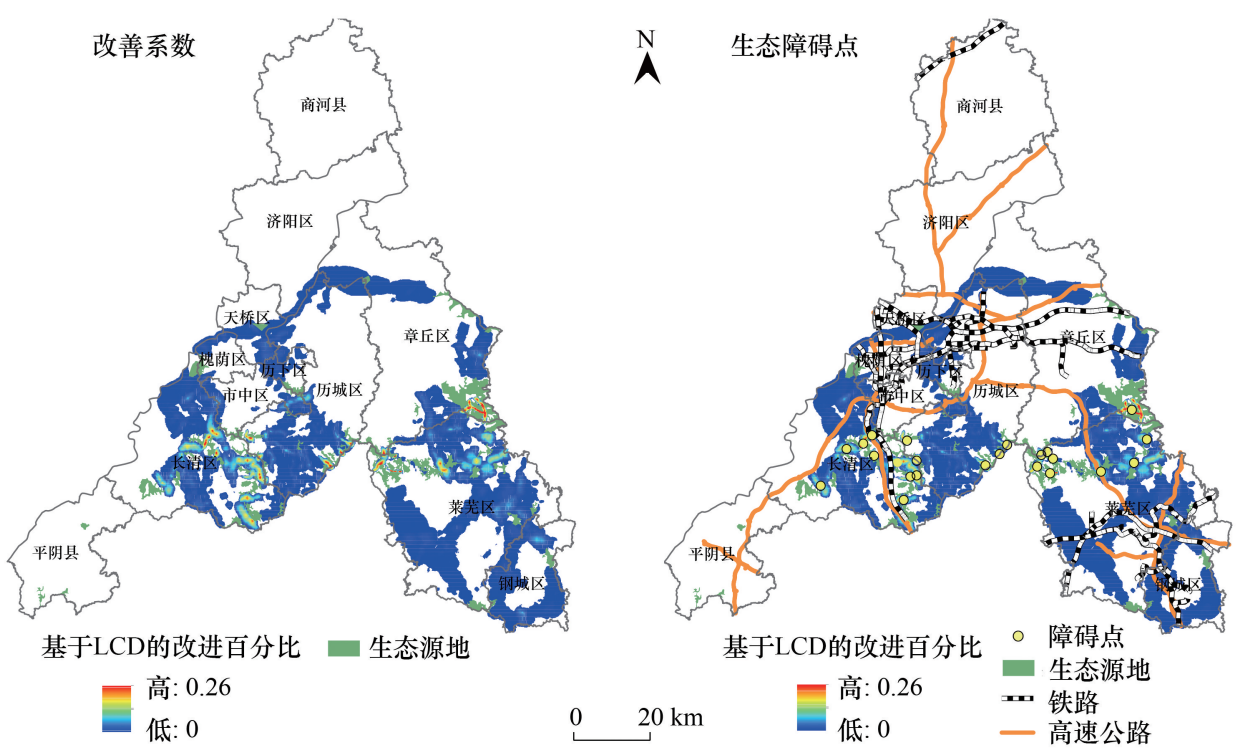

图 7 生态障碍点的识别

Fig.7 Recognition of ecological obstacle points

的农业用地、林地、建设用地分别占总节点面积的 $57.61 \% 、 36.53 \% 、 5.09 \%$ 。针对关键区域的修复提出以下修 复方向的建议。针对林地的保护修复,一是应该展开山地丘陵地区森林资源生态修复,注重实施新一轮退耕 还林, 因地制宜降低景观破碎化程度。二是在地质灾害防治为主的区域, 需通过加强边坡植被的管理, 加强地 质灾害防治工程建设。三是对低效林和疏林地,通过优化树种结构,提高森林质量,进一步提升林业碳汇能 力。针对农业用地的保护修复,一是应该积极推进全域土地综合整治工作,整体推进农用地整理,加强农田整 治工程, 实行生态农业。二是着力改善农田及周边生境, 恢复田间生物群落和生态链, 提高农田生态系统生物 多样性。三是进行乡村道路整治, 提高道路两旁的植被覆盖度以及植物多样性。针对建设用地的修复, 一是 道路布局方面应该注重避让周围生态用地,避免进一步影响生态空间破碎化。二是加强城市绿廊、绿楔、绿心 等系统建设,提高城市生态系统服务功能。三是利用低影响开发的理念改变路面和建筑屋顶的结构与特性, 改变路面的透水性质, 提高城市用地的生态系统的韧性。

表 2 济南市关键区域生态保护与生态修复策略

Table 2 Ecological restoration strategies of ecological pinch points and obstacles in Jinan City

\begin{tabular}{|c|c|c|c|c|}
\hline $\begin{array}{l}\text { 修复关键区 } \\
\text { Repair critical areas }\end{array}$ & $\begin{array}{l}\text { 土地利用现状 } \\
\text { land use types }\end{array}$ & $\begin{array}{l}\text { 行政区域 } \\
\text { Districts }\end{array}$ & $\begin{array}{l}\text { 分布位置 } \\
\text { Location }\end{array}$ & $\begin{array}{l}\text { 生态修复策略 } \\
\text { Ecological restoration strategy }\end{array}$ \\
\hline 需要保护的生态“夹点” & 林地 & 大王庄镇 & 温家峪、杨家圈村 & 1. 实施退耕还林还草、增加乡土植物的种植, 因地制宜选 \\
\hline Needed ecological protection & & 柳埠镇 & 川道村 & 择灌从等植被类型, 进一步降低景观破碎化程度 \\
\hline \multirow[t]{8}{*}{ "pinch point" } & & & $\begin{array}{l}\text { 南部山区-金牛山村、济泰高速、 } \\
\text { 柳埠国家森林公园 }\end{array}$ & $\begin{array}{l}\text { 2. 培育绿色生态廊道建设, 在铁路、公路、主要河流两侧 } \\
\text { 科学进行科学植树绿化,建设森林生态廊道 }\end{array}$ \\
\hline & & & $\begin{array}{l}\text { 突泉村、鹿宝泉村、望岳路 } \\
\text { S103 段 }\end{array}$ & 3. 加强林地资源监管和林带建设、以乡土树种植为主 \\
\hline & & & 北峪村北、金象山乐园 & \\
\hline & & & $\begin{array}{l}\text { 济泰高速大泉村段、红叶谷生态 } \\
\text { 旅游区 }\end{array}$ & \\
\hline & & 万德镇 & 南沙河东侧 & \\
\hline & & 五峰山街道 & 北套村-山东鲁润工业园西边 & \\
\hline & & 西营镇 & 大高尖山南 & \\
\hline & & 仲宫镇 & 鹿宝泉村北、露水岭 & \\
\hline
\end{tabular}




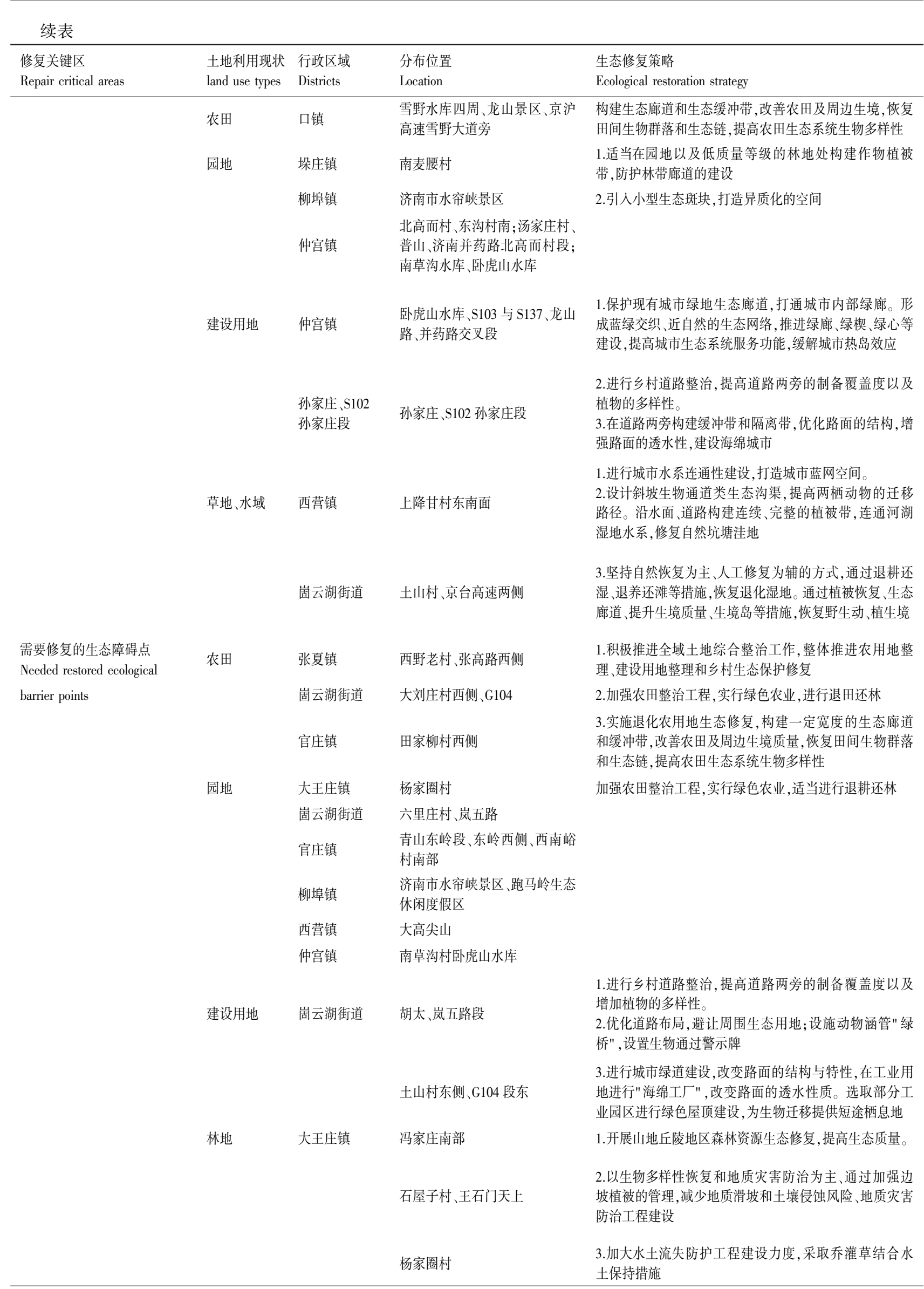




\begin{tabular}{|c|c|c|c|c|}
\hline $\begin{array}{l}\text { 修复关键区 } \\
\text { Repair critical areas }\end{array}$ & $\begin{array}{l}\text { 土地利用现状 } \\
\text { land use types }\end{array}$ & $\begin{array}{l}\text { 行政区域 } \\
\text { Districts }\end{array}$ & $\begin{array}{l}\text { 分布位置 } \\
\text { Location }\end{array}$ & $\begin{array}{l}\text { 生态修复策略 } \\
\text { Ecological restoration strategy }\end{array}$ \\
\hline \multirow{7}{*}{ Repair critical areas } & & 垛庄镇 & 南麦腰村 & $\begin{array}{l}\text { 4. 开展低效林、疏林地改造, 调整优化树种结构, 提高森 } \\
\text { 林质量, 提升碳汇能力 }\end{array}$ \\
\hline & & 官庄镇 & 上龙子村、渔湾村青山段 & \\
\hline & & 万德镇 & 店台村、北沙河旁、 & \\
\hline & & 五峰山街道 & 润玉泉村东北方、夹山 & \\
\hline & & 雪野镇 & $\begin{array}{l}\text { 邢家峪村、雪野大道旁、迟步沟 } \\
\text { 东部 }\end{array}$ & \\
\hline & & 仲宫镇 & $\begin{array}{l}\text { 张高路西侧、于盘村、杨而庄村- } \\
\text { 卧虎山水库 }\end{array}$ & \\
\hline & 水域 & 张夏镇 & 西野老村、张高路西侧 & $\begin{array}{l}\text { 实施水系连通工程,塑造健康自然的河流旁的绿道,保持 } \\
\text { 孤立且具备连通性的、自然的斑块, 为动物的迁徙提供短 } \\
\text { 暂的受食地和栖息地 }\end{array}$ \\
\hline
\end{tabular}

\section{3 讨论}

生态恢复区的改善是城市生态规划和生态修复工程规划重要的组成部分 ${ }^{[51]}$, 以往的研究对部分关键区 域进行识别并给出比较通用的生态修复措施, 并没有以加强市域整体生态连通性的视角给出明确的生态恢复 改善区域 ${ }^{[27]}$ 。在一些已确定的生态改善恢复区域 ${ }^{[13]}$, 仅提出了较为模糊的生态修复措施。这种方法对开展 落地性的市域尺度的生态修复难以起到明确的参考意义。本研究基于电路理论模型,构建了分区域、分层次 的生态恢复改善区域,并提出相关的措施。

研究得到需要生态改善面积为 $2994.84 \mathrm{~km}^{2}$ (图 $8)$ 。极重要改善区面积为 $96.1 \mathrm{~km}^{2}$, 占生态修复分区比 例为 $3.21 \%$, 主要分布在长清区东部、历城区西南部、莱 芜区北部, 用地类型主要为林地、农业用地, 两者共占极 重要改善区面积的 $78.03 \%$ 。重要改善区面积为 $340.481 \mathrm{~km}^{2}$, 面积占比为 $11.37 \%$, 用地类型主要为林 地、农业用地、建设用地，三者占重要改善区面积的 $91 \%$ 。首先, 可以看出极重要和重要改善区与生态“夹 点”、生态障碍点的范围分布较为重合, 生态修复改善 区的面积也几乎包含了所有的廊道。其次,通过叠加经 过地质灾害敏感性修正后的生态阻力面,可以发现极重 要和重要改善区同时也包含了阻力值较大、易发生地质 灾害的区域,如历城区的部分重要改善区。通过对上述 区域进行生态修复对提升济南市的景观连通性以及生 态安全格局稳定程度有重要意义。

考虑到进行不同级别的改善恢复区生态修复需要 不同的经济成本,例如部分改善区的土地利用类型为建 设用地等开发强度较大的区域,所以在生态修复过程中 要坚持“尊重自然、顺应自然、保护自然,自然恢复”的

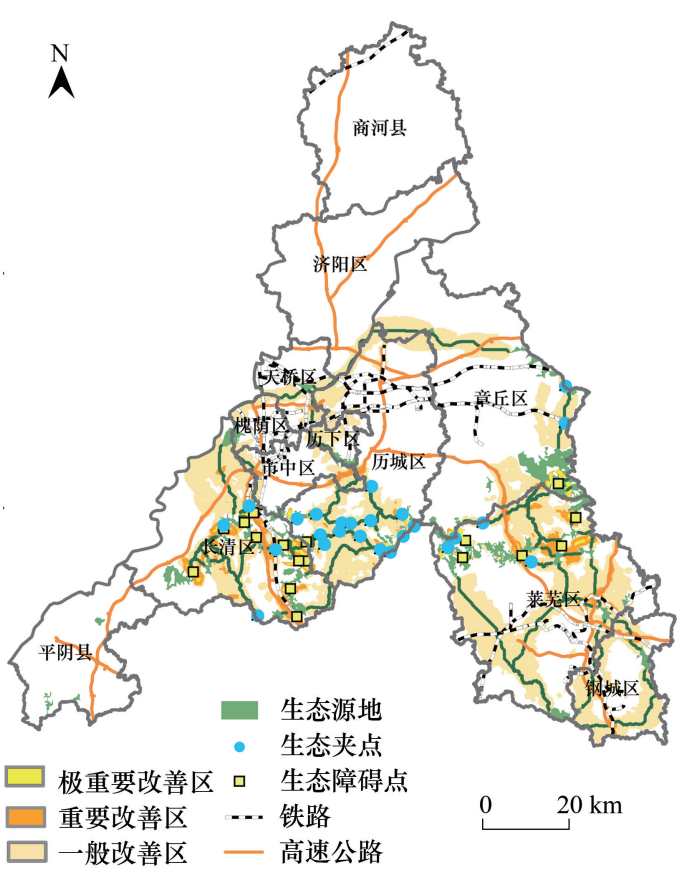

图 8 生态保护与修复分区

Fig.8 Ecological protection and restoration zones 理念, 坚持“宜林则林、宜草则草、宜荒则荒” 的修复原 则,分类施策,科学治理。基于此,本文确定的改善区提出如下生态修复措施。一是针对森林生态系统注意高 效保护和重点培育, 加强森林资源的调查与保护, 运用多种树种混交原则, 培育绿色生态廊道建设, 优化树种 
结构, 提升林地质量。加强破损山体综合治理修复, 实施一批国土绿化和森林生态屏障建设工程、破损山体生 态修复工程、采空塌陷区治理工程、地质灾害防治示范工程等系列工程。二是针对农业用地生态系统实施新 一轮土地综合整治, 实施高标准农田建设, 大力发展绿色农业, 提高土地的节约化和资源化水平。对存在退化 的农田实施农田改善工程, 充分依靠农田道路恢复本地的生物群落、田间生物栖息和繁衍的生态环境,构建农 田生态网络以维护农田生物多样性。实施一批生态化设计的土地平整工程、基于自然的解决方案的全域土地 综合整治试点示范工程、新型农村社区建设工程、田间生态化道路工程、田间生态沟渠、生物栖息地生态保护 工程等。三是针对城市建设用地生态系统加强城市水土修复, 加强城市科学绿化, 通过拆迁建绿、见缝插绿、 立体绿化、屋顶绿化等措施拓展城市生态空间,厚植“绿”的底色。探索“生态保育+气候适应性城市”、“海绵 城市” 等生态概念融人城市建设, 加强城市绿色基础设施的建设, 尤其是针对城市边界的大肆扩张造成的生 境缺失空间。增加城市应对气候变化的能力。进一步优化地面设计,改变下垫面的渗透性。注重实施一批城 市绿色生态网络碳汇建设工程、海绵城市建设工程、老旧公园绿色化改造工程。

然而, 本研究虽然在一定程度上识别济南的生态修复重点区域, 也提出相应的生态修复措施, 但考虑到济 南特殊的地质环境, 如果采用单一的工程措施进行生态修复, 必然对区域本地生态系统有一定的影响。首先, 例如识别的有 8 处关键区域位于铁路和公路附近, 极重要和重要区中存在部分建设用地, 如何统筹利用最低 的修复成本和以最低的生态环境影响进行生态修复? 其次, 如何将基于自然的解决方案 ( Nature Based Solution, NBS) 的理念融入国土空间生态保护修复全过程中, 既减少现有生境质量的干扰, 又使得修复区域的 利益相关方参与进来并获取生态效益。同时如何设计不同的生态修复情景, 并根据生态修复代价进行修复的 重点和顺序,在未来是一个重点也是难点。

\section{4 结论}

本研究基于生态源地、地质灾害敏感性修订的生态阻力面,利用电路理论模型提取生态廊道、生态夹点以 及障碍点,进一步划分生态改善区, 系统构建了 “点一线一面” 的生态安全格局同时为未来济南市生态修复提 供了方向。主要结论如下:

(1) 济南市生态源地数量为 35 个, 面积为 $567.15 \mathrm{~km}^{2}$, 占市域面积的 $5.54 \%$ 。生态廊道长度为 818.42

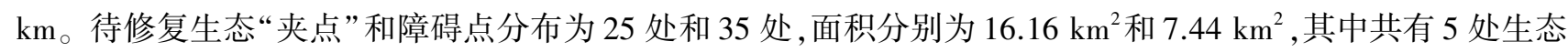
“夹点”与生态障碍点几乎重合, 是未来函需开展生态修复与保护的区域。其中生态修复关键区域主要分布 在历城区、章丘区、莱芜区、长清区。生态改善区面积共为 $2994.84 \mathrm{~km}^{2}$ 。

(2) 基于识别的生态保护修复的关键区域和生态改善区的空间格局分布,结合土地利用现状和卫星影 像, 本文提出各类生态保护与修复的重点方向以及生态修复重要工程措施指引。研究可为济南市国土空间生 态保护与修复规划和“十四五”生态保护规划提供参考, 同时对市域生态修复重大工程谋划具有一定的参考 价值。

\section{参考文献 (References) :}

[ 1 ] Adams S, Adom P K, Klobodu E K M. Urbanization, regime type and durability, and environmental degradation in Ghana. Environmental Science and Pollution Research, 2016, 23(23): 23825-23839.

[ 2 ] 吴健生, 曹祺文, 石淑芹, 黄秀兰, 卢志强. 基于土地利用变化的京津冀生境质量时空演变. 应用生态学报, 2015, 26(11): 3457-3466.

[ 3 ] 白立敏, 冯兴华, 孙瑞丰, 高漓. 生境质量对城镇化的时空响应——以长春市为例. 应用生态学报, 2020, 31(4) : 1267-1277.

[ 4 ] 史芳宁, 刘世梁, 安毅, 孙永秀, 董世鬼, 武雪. 城市化背景下景观破碎化及连接度动态变化研究——以昆明市为例. 生态学报, 2020 , $40(10): 3303-3314$.

[ 5 ] 付刚, 肖能文, 乔梦萍, 齐月, 闻冰, 刘高慧, 高晓奇, 李俊生. 北京市近二十年景观破碎化格局的时空变化. 生态学报, 2017, 37(8): 2551-2562.

[ 6 ] De León L F, Sharpe D M T, Gotanda K M, Raeymaekers J A M, Chaves J A, Hendry A P, Podos J. Urbanization erodes niche segregation in Darwin's finches. Evolutionary Applications, 2019, 12(7) : 1329-1343. 
［7］易行, 白彩全, 梁龙武, 赵子聪, 宋伟轩, 张妍. 国土生态修复研究的演进脉络与前沿进展. 自然资源学报, 2020, 35(1): 37-52.

［8］朱捷, 苏杰, 尹海伟, 孔繁花. 基于源地综合识别与多尺度嵌套的徐州生态网络构建. 自然资源学报, 2020, 35(8): 1986- 2001.

[ 9 ] 宋婷, 李岱青, 张林波, 王光镇, 高艳妮, 杨春艳, 冯朝阳, 马欢. 秦巴山脉区域生态系统服务重要性评价及生态安全格局构建. 中国工 程科学, 2020, 22(1): 64-72.

[10］应凌霄, 王军, 周妍. 闽江流域生态安全格局及其生态保护修复措施. 生态学报, 2019, 39(23) : 8857-8866.

[11］王浩, 马星, 杜勇. 基于生态系统服务重要性和生态敏感性的广东省生态安全格局构建. 生态学报, 2021, 41(5)：1705-1715.

[12] 方莹, 王静, 黄隆杨, 翟天林. 基于生态安全格局的国土空间生态保护修复关键区域诊断与识别一以烟台市为例. 自然资源学报, 2020, 35(1): 190-203.

[13] 倪庆琳, 丁忠义, 侯湖平, 贾宁凤, 王慧. 基于电路理论的生态格局识别与保护研究一一以宁武县为例. 干旱区资源与环境, 2019, 33 (5): 67-73.

[14] 倪庆琳, 侯湖平, 丁忠义, 李艺博, 李金融. 基于生态安全格局识别的国土空间生态修复分区一一以徐州市贾汪区为例. 自然资源学报, 2020, 35(1): 204-216.

[15] Peng J, Pan Y J, Liu Y X, Zhao H J, Wang Y L. Linking ecological degradation risk to identify ecological security patterns in a rapidly urbanizing landscape. Habitat International, 2018, 71: 110-124.

［16］许峰, 尹海伟, 孔繁花, 徐建刚. 基于 MSPA 与最小路径方法的巴中西部新城生态网络构建. 生态学报, 2015, 35(19): 6425-6434.

[17] 史芳宁, 刘世梁, 安毅, 孙永秀. 基于生态网络的山水林田湖草生物多样性保护研究一一以广西左右江为例. 生态学报, 2019, 39(23)： 8930-8938.

[18] 杜悦悦, 胡熠娜, 杨旸, 彭建. 基于生态重要性和敏感性的西南山地生态安全格局构建一一以云南省大理白族自治州为例. 生态学报, 2017, 37(24): 8241-8253.

[19］吴健生, 张理卿, 彭建, 冯喆, 刘洪萌, 赫胜涁. 深圳市景观生态安全格局源地综合识别. 生态学报, 2013, 33(13): 4125-4133.

[20］王越, 林箐. 基于 MSPA 的城市绿地生态网络规划思路的转变与规划方法探究. 中国园林, 2017, 33(5): 68-73.

[21] 王玉荣, 金晓斌, 沈春竹, 鲍桂叶, 刘晶, 周寅康. 东部发达区生态安全格局构建一一以苏南地区为例. 生态学报, 2019, 39(7)： 2298-2310.

[22]陈南南, 康帅直, 赵永华, 周煌杰, 间瑾, 卢雅茹. 基于 MSPA 和 MCR 模型的秦岭 (陕西段) 山地生态网络构建. 应用生态学报, 32(5)： 1545- 1553 .

[23] 吴健生, 马洪坤, 彭建. 基于 “功能节点一关键廊道” 的城市生态安全格局构建一一以深圳市为例. 地理科学进展, 2018, 37(12)： 1663- 1671 .

[24] 刘佳, 尹海伟, 孔繁花, 李沐寒. 基于电路理论的南京城市绿色基础设施格局优化. 生态学报, 2018, 38(12)：4363-4372.

[25] McRae B H, Beier P. Circuit theory predicts gene flow in plant and animal populations. Proceedings of the National Academy of Sciences of the United States of America, 2007, 104(50) : 19885-19890.

[26] Adriaensen F, Chardon J P, De Blust G, Swinnen E, Villalba S, Gulinck H, Matthysen E. The application of 'least-cost' modelling as a functional landscape model. Landscape and Urban Planning, 2003, 64(4) : 233-247.

[27] 付风杰, 刘珍环, 刘海. 基于生态安全格局的国土空间生态修复关键区域识别——贺州市为例. 生态学报, 2021, 41(9) : 3406-3414.

[28］李弘, 王彬畉, 孟格蕾, 向亚玲. 城市洪涝风险防控的生态修复途径. 上海城市管理, 2021, 30(2) : 87-96.

［29］关于印发《济南市 2020 年地质灾害防治方案》的通知. (2020-06-30). http://nrp.jinan.gov.cn/art/2020/6/30/art_43695_4510465.html.

[ 30] Peng S Z, Ding Y X, Liu W Z, Li Z. 1 km monthly temperature and precipitation dataset for China from 1901 to 2017. Earth System Science Data, 2019, 11(4) : 1931-1946.

[31］刘世梁, 侯笑云, 尹艺洁, 成方妍, 张月秋, 董世鬼. 景观生态网络研究进展. 生态学报, 2017, 37(12) : 3947-3956.

[32] 陈春娣, 吴胜军, Douglas M C, 吕明权, 温兆飞, 姜毅, 陈吉龙. 阻力赋值对景观连接模拟的影响. 生态学报, 2015, 35(22) : 7367-7376.

[33] Sutherland G D, Harestad A S, Price K, Lertzman K P. Scaling of natal dispersal distances in terrestrial birds and mammals. Conservation Ecology, 2000, 4(1): 16-16.

[34] 侍昊, 徐雁南. 基于景观连通性的城市绿地核心区规划方法研究. 南京林业大学学报: 自然科学版, 2011, 35(1): 51-56.

[35] 刘常富, 周彬, 何兴元, 陈玮. 沈阳城市森林景观连接度距离阈值选择. 应用生态学报, 2010, 21(10): 2508-2516.

[36] 郭家新, 胡振琪, 袁冬竹, 梁宇生, 李鹏宇, 杨坤, 浮耀坤. 黄河流域下游煤矿采煤塌陷区耕地破碎化动态演变一以济宁市为例. 煤炭 学报，2020. (2020-09-23). https://kns. cnki. net/KCMS/detail/detail. aspx? dbcode $=$ CJFQ\&dbname $=$ CAPJLAST\&filename $=$ MTXB20200922000.

[37］郭家新, 胡振琪, 李海霞,刘金兰, 张雪, 赖小君. 基于 MCR 模型的市域生态空间网络构建. 农业机械学报, 2021, 52(3): 275-284.

［38］谢慧玮, 周年兴, 关健. 江苏省自然遗产地生态网络的构建与优化. 生态学报, 2014, 34(22) : 6692-6700.

[39］尹海伟, 孔繁花, 祈毅, 王红扬, 周艳妮, 秦正茂. 湖南省城市群生态网络构建与优化. 生态学报, 2011, 31(10): 2863-2874. 
[40] 高阳, 刘悦忻, 钱建利, 郭游, 胡迎山. 基于多源数据综合观测的生态安全格局构建一一以江西省万年县为例. 资源科学, 2020, 42 (10) : 2010-2021.

[41] 黎晓亚, 马克明, 傅伯杰, 牛树奎. 区域生态安全格局: 设计原则与方法. 生态学报, 2004, 24(5): 1055-1062.

[42］肖淡，欧阳志云，朱春全,赵景柱，何国金，王效科. 岷山地区大熊猫生境评价与保护对策研究. 生态学报, 2004, 24(7)：1373-1379.

[43] 吴宁, 卢涛, 罗鹏, 朱单. 地震对山地生态系统的影响—— 5.12 汶川大地震为例. 生态学报, 2008, 28(12): 5810-5809.

[44] 苏泳娴, 张虹鸥, 陈修治, 黄光庆, 叶玉瑶, 吴旗韬, 黄宁生, 匡耀求. 佛山市高明区生态安全格局和建设用地扩展预案. 生态学报, 2013, 33(5): 1524-1534.

[45] 周锐, 王新军, 苏海龙, 钱欣, 孙冰. 基于生态安全格局的城市增长边界划定一一平顶山新区为例. 城市规划学刊, 2014, (4): 57-63.

[46] 彭建, 郭小楠, 胡熠娜, 刘炎序. 基于地质灾害敏感性的山地生态安全格局构建一一以云南省玉溪市为例. 应用生态学报, 2017, 28(2) : 627-635.

[47] 张美丽, 齐跃普, 张利, 陈影, 周亚鹏, 陈亚恒, 王树涛. 基于 Linkage Mapper 与粒度反推法的太行山中北段生态节点识别与分析一一以 河北省阜平县为例. 生态与农村环境学报, 2020, 36(12): 1569-1578.

[48] McRae B H, Hall S A, Beier P, Theobald D M. Where to restore ecological connectivity? Detecting barriers and quantifying restoration benefits. PLoS One, 2012, 7(12): e52604.

[49] Leonard P B, Duffy E B, Baldwin R F, McRae B H, Shah V B, Mohapatra T K. Gflow : software for modelling circuit theory-based connectivity at any scale. Methods in Ecology and Evolution, 2017, 8(4) : 519-526.

[50］马世发, 劳春华, 江海燕. 基于生态安全格局理论的国土空间生态修复分区模拟一一以奥港澳大湾区为例. 生态学报, 2021, 41(9)： 3441-3448

[51] Peng J, Zhao S Q, Dong J Q, Liu Y X, Meersmans J, Li H L, Wu J S. Applying ant colony algorithm to identify ecological security patterns in megacities. Environmental Modelling \& Software, 2019, 117: 214-222. 